DOI: https://doi.org/10.24127/ajpm.v10i2.3644

\title{
PROFIL KESALAHAN PEMECAHAN MASALAH KESEBANGUNAN DITINJAU DARI KEPERCAYAAN DIRI DAN KECEMASAN MATEMATIKA
}

\author{
Haniftia Haqqiendini Prabowo ${ }^{*}$, Riyadi $^{2}$, Sri Subanti $^{3}$ \\ 1,2,3 Pendidikan Matematika, Universitas Sebelas Maret, Surakarta, Indonesia \\ *Corresponding author. \\ E-mail: $\quad$ haniand.chan@gmail.com ${ }^{2 *}$ \\ riyadifkipuns@gmail.com ${ }^{2}$ \\ $\underline{\text { sri_subanti@yahoo.co.id }}^{3}$ )
}

Received 28 March 2021; Received in revised form 15 June 2021; Accepted 28 June 2021

\begin{abstract}
Abstrak
Tujuan dari penelitian adalah mendeskripsikan kesalahan pemecahan masalah kesebangunan ditinjau dari kepercayaan diri dan kecemasan matematika siswa SMP. Jenis penelitian ini adalah deskripif kualitatif. Data utama pada penelitian ini adalah hasil tes, kuesioner kepercayaan diri, kuesioner kecemasan matematika dan wawancara. Subjek penelitian ini yaitu siswa yang memiliki kepercayaan diri rendah, sedang dan tinggi dengan kecemasan matematika rendah, sedang dan tinggi. Siswa akan diberi tes untuk mengetahui kesalahan yang dilakukan. Wawancara dilakukan pada siswa yang paling banyak melakukan kesalahan. Hasil penelitian ini menunjukkan bahwa siswa yang memiliki kepercayaan diri rendah, sedang maupun tinggi dengan kecemasan matematika rendah, sedang maupun tinggi melakukan kesalahan konsep pada tahap menyusun strategi untuk memecahkan masalah. Kesalahan lain yang dilakukan adalah kesalahan strategi pada tahap melaksanakan strategi yang telah direncanakan dan kesalahan operasi hitung pada tahap melakukan pemeriksaan kembali.
\end{abstract}

Kata Kunci: Kecemasan matematika; kepercayaan diri; kesalahan; pemecahan masalahan.

\begin{abstract}
The aims from this research are to describe the mistake of solving kesebangunan problems in terms of the self confidence and mathematics anxiety of junior high school students. This type of this research is qualitative descriptive. The main data of this research are test results, self-confidence questionnaires results, mathematics anxiety questionnaires results and interviews results. The subject of this research are the students who have low, medium and high self-confidence with low, medium and high mathematics anxiety. The student will be given a test to find out the mistakes. Interviews were conducted to students who made the most mistakes. The results of this research indicated that students who have low, medium or high self-confidence with low, medium or high math anxiety make a mistake of concept at the stage of formulating strategies to solve problems. The mistake of strategy that many students made were removing unit data in the arithmetic operation process at the stage of implementing the planned strategy. The other mistakes made were a mistake of strategy in the stage of carry out the planned strategy and a mistake of counting operations in the stage of re-examination.
\end{abstract}

Keywords: Mathematics anxiety; mistake; problems solving; self confidence.

This is an open access article under the Creative Commons Attribution 4.0 International License

\section{PENDAHULUAN}

Faktor yang mampu menghasilkan sumber daya manusia dengan kompetensi utuh yang berkulitas adalah pendidikan. Melalui pendidikan diharapkan akan memperbaiki dan mengangkat derajat manusia. Mengajarkan matematika kepada siswa merupakan bentuk mempersiapkan siswa untuk mengarungi hidup di masa 
depan. Matematika merupakan ilmu yang mendasari perkembangan teknologi, karena mempunyai peran penting dalam berbagai disiplin ilmu dan memajukan daya pikir manusia (Ulya, 2016). Pada dasarnya matematika adalah penyelesaian masalah dan dalam menyelesaikan masalah, selain menuntut siswa untuk berpikir juga menyebabkan siswa lebih kreatif (Mukeriyanto, Mastur \& Mulyono, 2019). Pembelajaran matematika harus mengutamakan untuk berpikir sistematis, kritis dan kemampuan pemecahan masalah (Yuwono, Supanggih \& Ferdiani, 2018). Membiasakan siswa berlatih menyelesaiakan masalah matematika dalam kegiatan pembelajaran menjadi salah satu cara agar siswa terbiasa memecahkan masalah matematika.

Pemecahan masalah merupakan suatu proses untuk mengatasi kesulitankesulitan yang dihadapi untuk mencapai tujuan yang diharapkan (Sumartini, 2016). Pemecahan masalah merupakan suatu proses berpikir siswa/ mahasiswa yang mampu menumbuhkan ketrampilan memahami masalah, menganalisis masalah dengan menggunakan penafsiran dan penalaran untuk menyelesaikan masalah, serta mengevaluasi penyelesaian yang dikerjakan dan merefleksikannya (Anugraheni, 2019). Dalam hal ini, pemecahan masalah dapat diartikan sebagai proses menyelesaikan masalah yang diawali dengan memahami masalah, menyusun strategi untuk memecahkan masalah, melaksanakan strategi yang telah direncanakan dan melakukan pemeriksaan kembali.

Pada proses pemecahan masalah, kesalahan mungkin saja terjadi. Kesalahan yang dilakukan akan memepengaruhi hasil akhir pemecahan masalah. Berdasarkan data hasil
USBN/USBK matematika pada tahun 2018/2019, persentase siswa SMP Negri 1 Sambungmacan menjawab benar pada indikator menghitung panjang unsur tertentu dalam kesebangunan adalah 19,60 dari 250 siswa. Hal ini menunjukan bahwa ada siswa yang masih melakukan kesalahan dalam menyelesaikan soal kesebangunan.

Menurut Irfan (2017) Kesalahankesalahan tersebut dapat timbul karena kurangnya pemahaman, kurang percaya diri, dan mengalami kecemasan belajar matematika. Kepercayaan diri atau self confidence siswa mampu memberi dorongan kepada siswa untuk menghadapi permasalahan matematika. Banyak masalah yang timbul karena seseorang tidak memiliki kepercayaan diri, misalnya siswa yang mencontek saat ujian merupakan salah satu contoh bahwa siswa tersebut tidak percaya pada kemampuan dirinya sendiri, ia lebih mengantungkan kepercayaan pada pihak lain (Fenti, Sudia \& Kadir, 2020). Individu yang memiliki kepercayaan diri yang baik memiliki keyakinan dan selalu berusaha mengembangkan potensi diri secara maksimal serta menunjukan yang terbaik dari dirinya dibuktikan dengan sebuah prestasi (Komara, 2016). Jika seseorang memiliki percaya diri rendah, maka individu tersebut cenderung menutup diri, mudah frustasi ketika menghadapi kesulitan, canggung dalam menghadapi orang, dan sulit menerima realita dirinya (Aristiani, 2016).

Kesalahan pemecahan masalah matematika dapat juga dipengaruhi oleh kecemasan matematika. Ketika melaksanakan tes hasil belajar banyak faktor yang dapat mempengaruhi salah satunya adalah faktor internal yaitu faktor yang berasal dari dalam diri siswa yaitu kecemasan yang dialami oleh siswa (Ekawati, 2015). Menurut 
Saputra (2014), Kecemasan matematika merupakan bentuk perasaan seseorang baik berupa perasaan takut, tegang ataupun cemas dalam menghadapi persoalan matematika atau dalam melaksanakan pembelajaran matematika dengan berbagai bentuk gejala yang ditimbulkan.

Penelitian terkait pemecahan masalah, kepercayaan diri dan kecemasan matematika telah dilakukan Lutfiyah, Rukmigarsari \& Fathani (2019), disampaikan bahwa semakin tinggi kecemasan matematika siswa maka kemampuan pemecahan masalahnya semakin rendah, semakin tinggi kepercayaan diri siswa maka semakin tinggi pula kemampuan pemecahan masalah matematisnya dan ada pengaruh bermakna kecemasan matematika dan kepercayaan diri secara bersama-sama terhadap kemampuan pemecahan masalah matematis siswa. Adapun penelitian terkait kepercayaan diri pernah dilakukan oleh Aristiani. Aristiani (2016) menyampaikan bahwa jika siswa memiliki bekal percaya diri yang baik, maka individu tersebut akan dapat mengembangkan potensinya dengan mantap. Namun jika siswa memiliki percaya diri rendah, maka individu tersebut cenderung menutup diri, mudah frustasi ketika menghadapi kesulitan, canggung dalam menghadapi orang, dan sulit menerima realita dirinya. Memiliki percaya diri yang tinggi dalam diri siswa dapat membantu mencapai prestasi dan hasil belajar yang lebih baik lagi. Penelitian lain terkait kecemasan matematika pernah dilakukan oleh Disai, Dariyo \& Basaria (2014), disampaikan bahwa semakin tinggi kecemasan matematika maka semakin rendah juga hasil belajar matematika siswa dan semakin rendah kecemasan matematika maka akan semakin tinggi hasil belajar matematika siswa.

Pemaparan beberapa penelitian tersebut merupakan penelitian terkait pemecahan masalah yang mengaitkan dengan kecemasan matematika siswa, pemecahan masalah terkait dengan kepercayaan diri. Berdasarkan uraian yang telah dipaparkan, penelitian ini mengarah pada kebaruan dan orisinalitas berkaitan dengan kesalahan pemecahan masalah ditinjau dari kepercayaan diri dan kecemasan matematika. Penilitian ini bertujuan untuk mendeskripsikan kesalahan pemecahan masalah kesabangunan ditinjau dari kepercayaan diri dan kecemasan matematika.

\section{METODE PENELITIAN}

Jenis penelitian ini adalah deskripif kualitatif. Penelitian dilakukan di SMP Negri 1 Sambungmacan pada semester genap tahun ajaran 2020/2021. Subjek dalam penelitian ini adalah 31 siswa kelas IX H. Teknik pengambilan sampel menggunakan teknik purposive sampling dengan pertimbangan tertentu yaitu: a) subjek telah mendapatkan materi kesebangunan, b) subjek merupakan siswa yang paling banyak melakukan kesalalahan pada tes dalam kelompok tertentu sehingga memudahkan untuk menjelajahi situasi yang diteliti.

Instrumen pengumpulan data yang digunakan adalah kuesioner kepercayaan diri, kuesioner kecemasan matematika, tes pemecahan masalah kesebangunan dan wawancara. Penelitian ini menggunakan metode triangulasi untuk memeriksa kesesuaian makna data yang diperoleh dari hasil tes dan wawancara.

Pemilihan subjek penelitian diawali dengan pemberian kuesioner 
DOI: https://doi.org/10.24127/ajpm.v10i2.3644

kepercayaan diri dan kuesioner kecemasan matematika berdasarkan kategori rendah, sedang dan tinggi. Pengambilan data selanjutnya adalah memberikan tes pemecahan masalah untuk mengetahui kesalahan pemecahan masalah kesebangunan. Langkah selanjutnya adalah wawancara dan menganalisis kesalahan pemecahan masalah. Tahapan akhir dari penelitian ini adalah menyimpulkan hasil analisis kesalahan pemecahan masalah kesebangu-nan ditinjau dari kepercayaan diri dan kecemasan matematika.

Adapun aspek dan indikator kepercayaan diri yang digunakan dalam penelitian ini disajikan pada Tabel 1 dan aspek serta indikator kecemasan matematika yang digunakan disajikan dalam Tabel 2.

Tabel 1. Aspek dan indikator kepercayaan diri

\begin{tabular}{ll}
\hline \multicolumn{1}{c}{ Aspek } & \multicolumn{1}{c}{ Indikator } \\
\hline Optimis & 1. Berusaha menghadapi masalah dengan tetap berpikir positif \\
Tanggung Jawab & 1. Bertangung jawab tehadap tugas yang diberikan \\
Rasional & $\begin{array}{l}\text { 1. Memiliki pemikiran yang terbuka } \\
\text { 2. Hati yang lapang }\end{array}$ \\
Keyakinan & atas \\
kemampuan diri & 2. Yakin dalam menentukan langkah penyelesaian masalah \\
\hline
\end{tabular}

Tabel 2. Aspek dan indikator kecemasan matematika

\begin{tabular}{ll}
\hline \multicolumn{1}{c}{ Aspek } & \multicolumn{1}{c}{ Indikator } \\
\hline Knowledge & 1. Memiliki perasaan tidak berdaya saat belajar matematika \\
Somatic & 1. Tegang ketika belajar matematika \\
& 2. Gugup ketika diberi soal \\
& 3. Khawatir atau gelisah \\
4. Panik ketika tes matametika \\
Cognitif & 1. Sering lupa dengan materi matematika ketika menghadapi tes \\
Attitude & 1. Tidak menyukai pelajaran matematika \\
\hline
\end{tabular}

Pada penelitian ini terdapat skala pengukuran untuk mengetahui kedudukan siswa dalam suatu kelompok berdasarkan tingkat kepercayaan diri dan kecemasan matematika. Skala yang digunakan pada kuesioner adalah skala interval yang kemudian diubah ke dalam skala ordinal dengan tiga kategori yaitu rendah, sedang, dan tinggi. Skala pengukuran mengadaptasi dari skala pengukuran yang dilakukan oleh Budiyono (2017). Skala pengukuran pada penelitian ini disajikan dalam Tabel 3 dan Tabel 4.
Tabel 3. Skala pengukuran kepercayan diri

\begin{tabular}{ccc}
\hline Interval & Kategori & $\begin{array}{c}\text { Banyak } \\
\text { Siswa }\end{array}$ \\
\hline$x<96,6444$ & Rendah & 5 \\
$96,6444 \leq x$ & Sedang & 18 \\
$\leq 103,8556$ & Tinggi & 8 \\
$x>103,8556$ & \\
\hline
\end{tabular}

Tabel 4. Skala pengukuran kecemasan matematika

\begin{tabular}{ccc}
\hline Interval & Kategori & $\begin{array}{c}\text { Banyak } \\
\text { Siswa }\end{array}$ \\
\hline$x<90,7761$ & Rendah & 9 \\
$90,7761 \leq x$ & Sedang & 15 \\
$\leq 100,5364$ & Tinggi & 7 \\
$x>100,5364$ & \\
\hline
\end{tabular}


DOI: https://doi.org/10.24127/ajpm.v10i2.3644

Tahap selanjutnya, dilakukan pengklasifikasian subjek penelitian kedalam 9 kelompok berdasarkan hasil kuesioner kepercayaan diri dan kuesioner kecemasan matematika. Klasifikasi subjek penelitian disajikan dalam Tabel 5.

Tabel 5. Klasifikasi subjek penelitian

\begin{tabular}{llccc}
\hline & & \multicolumn{3}{c}{ Kecemasan Belajar $(\mathbf{B})$} \\
\cline { 3 - 5 } & & Rendah $\left(\mathbf{b}_{\mathbf{1}}\right)$ & Sedang $\left(\mathbf{b}_{\mathbf{2}}\right)$ & Tinggi $\left(\mathbf{b}_{\mathbf{3}}\right)$ \\
\hline \multirow{3}{*}{ Kepercayaan Diri (A) } & Rendah $\left(\mathrm{a}_{1}\right)$ & 1 siswa & 1 siswa & 3 siswa \\
& Sedang $\left(\mathrm{a}_{2}\right)$ & 3 siswa & 11 siswa & 4 siswa \\
& Tinggi $\left(a_{3}\right)$ & 5 siswa & 3 siswa & 0 siswa \\
\hline
\end{tabular}

Pada setiap kelompok diambil 1 siswa yang paling banyak melakukan kesalahan. Indikator kesalahan yang digunakan dalam penelitian ini adalah (1) kesalahan konsep; (2) kesalahan strategi dan (3) kesalahan operasi hitung. Macam kesalahan konsep yang dilakukan siswa yaitu salah dalam menuliskan data yang diketahui, salah dalam menentukan data yang ditanyakan, salah dalam menutukan prasyarat berlakunya rumus dan menggunakan rumus yang tidak tepat. Macam kesalahan strategi yang dilakukan siswa yaitu tidak menentukan nilai yang diperlukan terlebih dahulu, menghilangkan data yang diperlukan dan menuliskan langkah yang tidak urut. Macam kesalahan operasi yang dilakukan siswa berupa salah dalam menuliskan operasi hitung, salah menuliskan bilangan pada proses operasi hitung dan salah dalam menentukan nilai akhir. Langkah selanjutnya adalah wawancara terhadap siswa yang paling banyak melakukan kesalahan. Adapun indikator pemecahan masalahan yang digunakan pada masing - masing langkah dalam penelitian ini disajikan dalam Tabel 6.

Tabel 6. Langkah dan indikator pemecahan masalah

\begin{tabular}{ll}
\hline \multicolumn{1}{c}{ Langkah } & \multicolumn{1}{c}{ Indikator } \\
\hline Siswa memahami masalah & 1. Mengetahui data yang diketahui \\
& 2. Mengetahui data yang ditanyakan \\
Siswa menyusun strategi untuk memecahkan & 3. Mengetahui data yang diperlukan \\
masalah & 1. Rumus sesuai dengan syarat kesebangunan \\
Siswa melaksanakan strategi yang $\quad$ telah & 1. Mengurun langkah secara urut \\
direncanakan & 2. Melakukan operasi hitung dengan tepat \\
Siswa melakukan pemeriksa kembali & 1. Membaca kembali soal \\
& 2. Memastikan kembali langkah \\
& 3. Memeriksa kembali operasi hitung \\
\hline
\end{tabular}

Tahap setelah wawancara yaitu penarikan kesimpulan dan verifikasi data. Hasil yang diperoleh dari tahapan ini akan menjadi temuan baru berupa kesalahan pemecahan masalah kesebangunan dari masing-masing subjek penelitian.

\section{HASIL DAN PEMBAHASAN}

Berdasarkan hasil pengklasifikasian subjek penelitian pada tabel 9 , selanjutnya dipilih 1 siswa disetiap kategori yang paling banyak melakukan kesalahan pada tes pemecahan masalah. 
Data tes dan wawancara pemecahan masalah disajikan sebagai berikut :

1. Siswa yang memiliki kepercayaan diri rendah dengan kecemasan matematika rendah $\left(a_{1} b_{1}\right)$

Jawaban tes tertulis pemecahan masalah kesebangunan oleh $a_{1} b_{1}$ dapat dilihat pada Gambar 1.

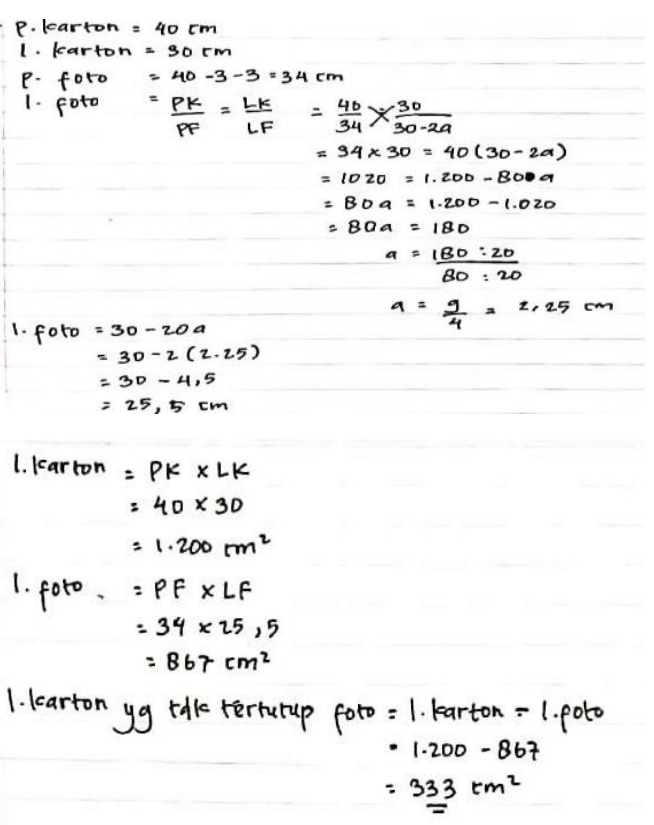

Gambar 1. Jawaban tes siswa $a_{1} b_{1}$

Berdasarkan hasil tes dan wawancara dengan siswa $a_{1} b_{1}$. siswa $\mathrm{a}_{1} \mathrm{~b}_{1}$ tidak melakukan kesalahan pada tahap memahami masalah. Kesalahan konsep dilakukan oleh siswa $\mathrm{a}_{1} \mathrm{~b}_{1}$ pada tahap menyusun strategi untuk memecahkan masalah. Siswa $a_{1} b_{1}$ tidak menggunakan dengan tepat untuk menghitung panjang foto dan lebar foto. Pada tahap melaksanakan strategi yang telah direncanakan terjadi kesalahan strategi karena menghilangkan data yang diperlukan. Siswa $a_{1} b_{1}$ tidak menggunakan satuan panjang pada proses operasi hitung. Pada tahap melakukan pemeriksaan kembali terjadi kesalahan operasi hitung. Kesalahan operasi hitung yang dilakukan adalah salah menentukan nilai akhir.
2. Siswa yang memiliki kepercayaan diri rendah dengan kecemasan matematika sedang $\left(a_{1} b_{2}\right)$

Jawaban tes tertulis pemecahan masalah kesebangunan oleh $a_{1} b_{2}$ dapat dilihat pada Gambar 2.

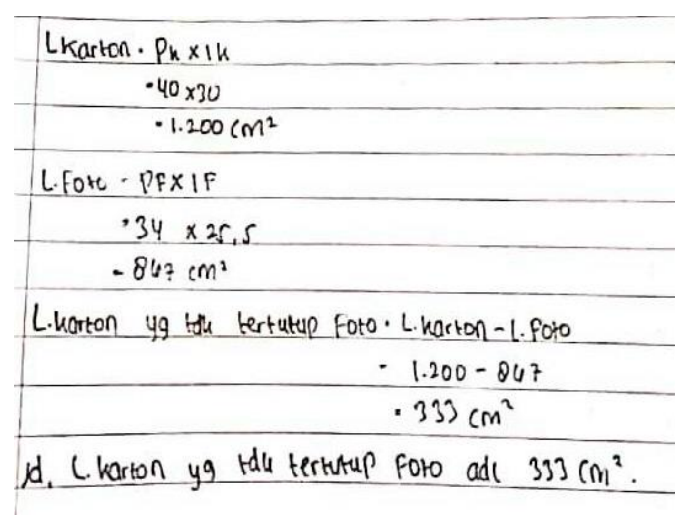

Gambar 2. Jawaban tes siswa $a_{1} b_{2}$

Berdasarkan hasil tes dan wawancara dengan siswa $a_{1} b_{2}$, siswa $\mathrm{a}_{1} \mathrm{~b}_{2}$ tidak melakukan kesalahan pada tahap memahami masalah. Pada tahap menyusun strategi untuk memecahkan masalah, terjadi kesalahan konsep. Siswa $\mathrm{a}_{1} \mathrm{~b}_{2}$ memperoleh hasil menghitung panjang foto dan lebar foto yang salah. Pada tahap melaksanakan strategi yang telah direncanakan, siswa $\mathrm{a}_{1} \mathrm{~b}_{2}$ melakukan kesalahan strategi karena menghilangkan data yang diperlukan. Data tersebut adalah satuan panjang pada proses operasi hitung. Pada tahap pemeriksaan kembali terjadi kesalahan operasi hitung berupa kesalahan dalam menentukan hasil akhir.

3. Siswa yang memiliki kepercayaan diri rendah dengan kecemasan matematika tinggi $\left(a_{1} b_{3}\right)$

Jawaban tes tertulis pemecahan masalah kesebangunan oleh $a_{1} b_{3}$ dapat dilihat pada Gambar 3. 
DOI: https://doi.org/10.24127/ajpm.v10i2.3644

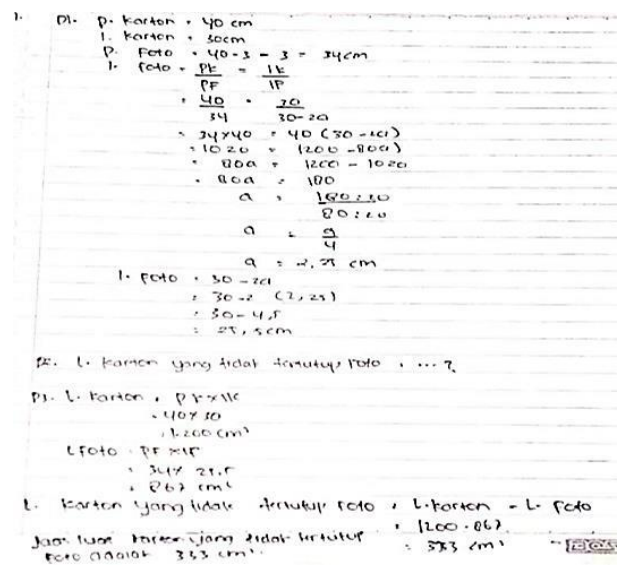

Gambar 3. Jawaban tes siswa $a_{1} b_{3}$

Berdasarkan hasil tes dan wawancara dengan siswa $a_{1} b_{3}$, siswa $\mathrm{a}_{1} \mathrm{~b}_{3}$ tidak melakukan kesalahan pada tahap memahami masalah. Pada tahap menyusun strategi untuk memecahkan masalah terjadi kesalahan konsep Siswa $a_{1} b_{3}$ menggunakan rumus yang tidak tepat untuk menghitung panjang foto dan lebar foto. Pada tahap melaksanakan strategi yang telah direncanakan terjadi kesalahan strategi karena menghilangkan data yang diperlukan. Siswa $a_{1} b_{3}$ tidak menggunakan satuan panjang pada proses operasi hitung. Pada tahap melakukan pemeriksaan kembali terjadi kesalahan operasi hitung karena siswa $a_{1} b_{3}$ salah menentukan nilai akhir.

4. Siswa yang memiliki kepercayaan diri sedang dengan kecemasan matematika rendah $\left(a_{2} b_{1}\right)$

Jawaban tes tertulis pemecahan masalah kesebangunan oleh $a_{2} b_{1}$ dapat dilihat pada gambar 4 .

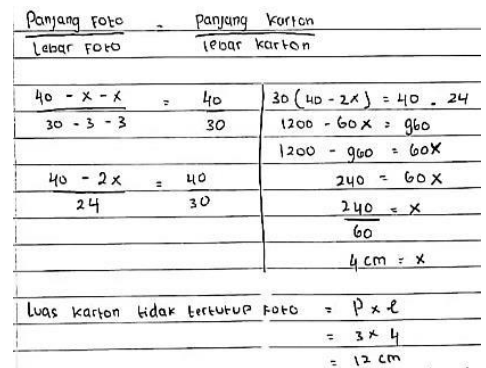

Gambar 4. Jawaban tes siswa $a_{2} b_{1}$
Berdasarkan hasil tes dan wawancara dengan siswa $a_{2} b_{1}$, pada tahap memahami masalah terjadi kesalahan konsep karena menggunakan rumus yang tidak tepat untuk menghitung luas karton yang tidak tertup foto. Pada tahap menyusun strategi untuk memecahkan masalah, siswa $a_{2} b_{1}$ melakukan kesalahan konsep karena tidak menyajikan data yang diperlukan dengan benar. Siswa $a_{2} b_{1}$ tidak menghitung panjang dan lebar foto terlebih dulu. Pada tahap melaksanakan strategi yang telah direncanakan terjadi kesalahan strategi karena ada data yang dihilangkan. Data yang dihilangkan adalah satuan panjang pada proses operasi hitung. Selain itu satuan yang digunakan untuk luas tidak tepat. Pada proses memeriksa kembali, siswa $a_{2} b_{1}$ melakukan kesalahan operasi hitung berupa kesalahan dalam menentukan nilai akhir.

5. Siswa yang memiliki kepercayaan diri sedang dengan kecemasan matematika sedang $\left(a_{2} b_{2}\right)$

Jawaban tes tertulis pemecahan masalah kesebangunan oleh $a_{2} b_{2}$ dapat dilihat pada gambar 5 .

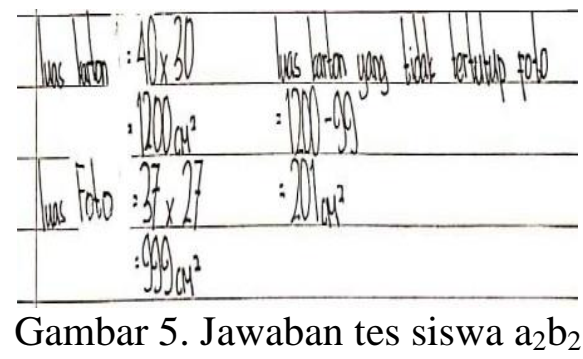

Berdasarkan hasil tes dan wawancara dengan siswa $a_{2} b_{2}$, siswa $\mathrm{a}_{2} \mathrm{~b}_{2}$ tidak melakukan kesalahan pada proses memahami masalah. Pada tahap menyusun strategi untuk memecahkan masalah, terjadi kesalahan konsep karena hasil menghitung panjang foto dan lebar foto yang diperoleh salah. 
Pada tahap melaksanakan strategi yang telah direncanakan, siswa $\mathrm{a}_{2} \mathrm{~b}_{2}$ melakukan kesalahan strategi karena menghilangkan data yang diperlukan. Data tersebut adalah satuan panjang pada proses operasi hitung. Pada tahap pemeriksaan kembali terjadi kesalahan operasi hitung karena salah dalam menentukan hasil akhir.

6. Siswa yang memiliki kepercayaan diri sedang dengan kecemasan matematika tinggi $\left(a_{2} b_{3}\right)$

Jawaban tes tertulis pemecahan masalah kesebangunan oleh $a_{2} b_{3}$ dapat dilihat pada Gambar 6.

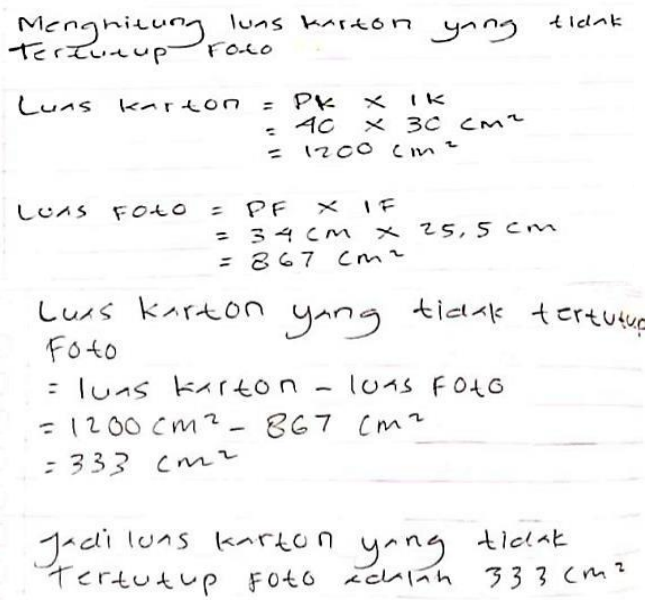

Gambar 6. Jawaban tes siswa $a_{2} b_{3}$

Berdasarkan hasil tes dan wawancara yang dilakukan oleh siswa $\mathrm{a}_{2} \mathrm{~b}_{3}$, tidak ada kesalahan pada tahap memahami masalah. Pada tahap menyusun strategi yang telah direncanakan terjadi kesalahan konsep karena hasil menghitung panjang foto dan lebar foto tidak tepat. Pada tahap melaksanakan strategi yang telah direncanakan terjadi kesalahan srategi karena data yang disajikan tidak urut. Siswa $a_{2} b_{3}$ tidak menuliskan proses menghitung panjang dan lebar foto. Pada tahap memeriksa kembali terjadi kesalahan operasi hitung karena salah dalam menentukan nilai akhir.
7. Siswa yang memiliki kepercayaan diri tinggi dengan kecemasan matematika rendah $\left(a_{3} b_{1}\right)$

Jawaban tes tertulis pemecahan masalah kesebangunan oleh $a_{3} b_{1}$ dapat dilihat pada gambar 7 .

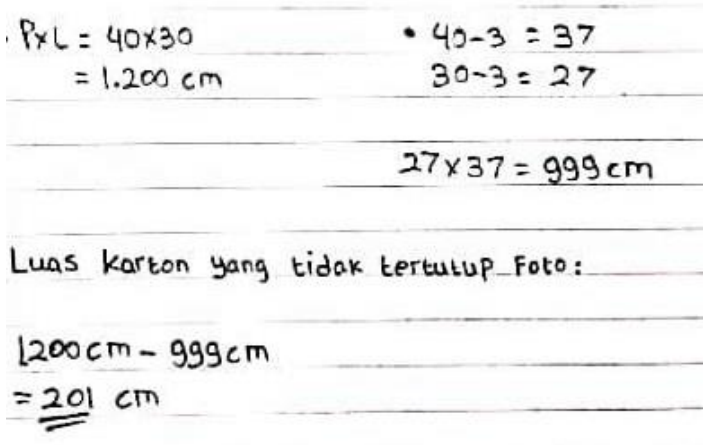

Gambar 7. Jawaban tes siswa $a_{3} b_{1}$

Berdasarkan hasil tes dan wawancara dengan siswa $a_{3} b_{1}$, ada tahapan memahami masalah tidak terjadi kesalahan. Kesalahan terjadi pada tahapan menyusun strategi. Kesalahan yang dilakukan oleh siswa $\mathrm{a}_{3} \mathrm{~b}_{1}$ adalah kesalahan konsep. Siswa $a_{3} b_{1}$ memperoleh hasil menghitung panjang foto dan lebar foto yang salah. Pada tahap melaksanakan strategi yang direncanakan terjadi kesalahan strategi karena menghilangkan data yang diperlukan. Siswa $a_{3} b_{1}$ tidak menuliskan satuan pada proses operasi hitung dan satuan luas yang digunakan tidak tepat. Pada tahap memeriksa kembali terjadi kesalahan operasi hitung karena siswa $a_{3} b_{1}$ salah dalam menentukan nilai akhir.

8. Siswa yang memiliki kepercayaan diri tinggi dengan kecemasan matematika sedang $\left(a_{3} b_{2}\right)$

Jawaban tes tertulis pemecahan masalah kesebangunan oleh $a_{3} b_{2}$ dapat dilihat pada Gambar 8. 
DOI: https://doi.org/10.24127/ajpm.v10i2.3644

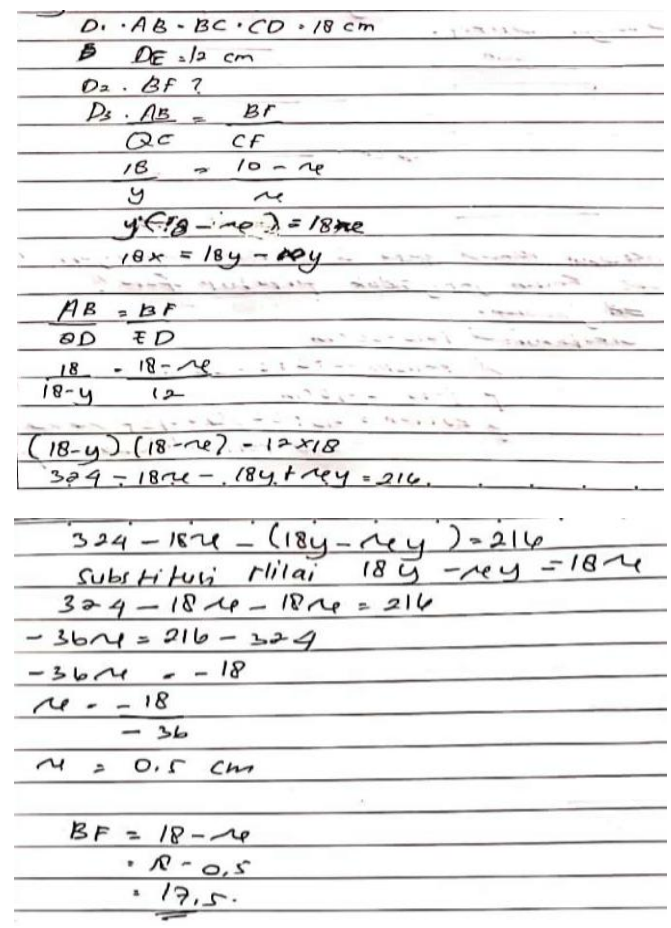

Gambar 8. Jawaban tes siswa $a_{3} b_{2}$

Berdasarkan hasil tes dan wawancara dengan siswa $a_{3} b_{2}$, pada tahapan memahami masalah terjadi kesalahan konsep karena salah memahami data yang diketahui, ditanyakan dan diperlukan. Kesalahan konsep juga terjadi pada tahap menyusun strategi untuk memecahkan masalah. Siswa $a_{3} b_{2}$ menggunakan syarat kesebangunan yang tidak tepat. Pada tahap melaksanakan strategi yang direncanakan terjadi kesalahan strategi karena siswa $a_{3} b_{2}$ menghilangkan data yang diperlukan. Data tersebut adalah satuan pada proses operasi hitung. Pada tahap memeriksa kembali terjadi kesalahan operasi hitung berupa kesalahan dalam menentukan nilai akhir dan tidak sesuai dengan data yang ditanyakan.

Pemecahanan masalah terdiri dari beberapa tahapan untuk menyelesaiakan masalah. Pada beberapa tahapan terjadi kesalahan. Kesalahan tersebut terlihat dari analisis penelitian ini. Disimpulkan bahwa siswa yang memiliki kepercayaan diri rendah, sedang dan tinggi dengan kecemasan matematika rendah, sedang dan tinggi melakukan kesalahan konsep pada tahap menyusun strategi untuk memecahkan masalah. Kesalahan strategi yang banyak dilakukan adalah menggunakan rumus yang tidak tepat. Siswa yang memiliki kepercayaan diri rendah, sedang dan tinggi dengan kecemasan matematika rendah, sedang dan tinggi melakukan kesalahan strategi pada tahap melaksanakan strategi yang telah direncanakan. Kesalahan strategi yang banyak dilakukan siswa adalah menghilangkan data satuan pada proses operasi hitung. Pada tahap melakukan pemeriksaan kembali terjadi kesalahan operasi hitung yang dilakukan oleh siswa yang memiliki kepercayaan diri rendah, sedang dan tinggi dengan kecemasan matematika rendah, sedang dan tinggi. Kesalahan perasi hitung yang banyak terjadi adalah salah menentukan nilai akhir.

Hal ini dapat dikaitkan dengan pendapat Purnama \& Mertika (2018) bahwa kepercayaan diri seseorang sangatlah berpengaruh dalam kemampuan pemecahan masalah, seseorang yang memiliki kepercayaan diri yang tinggi sangat membantu dalam penyelesaian tugas pemecahan masalah. Menurut Sukendra (2018) Kecemasan bisa menjadi faktor penghalang dalam belajar terutama belajar matematika, karena dapat mempengaruhi pola pikir dan emosi peserta didik. Ningsi (2018) berpendapat bahwa biasanya siswa akan sangat sering melakukan kesalahan ketika proses memahami soal, menyusun strategi, melaksanakan strategi, atau memeriksa ulang hasil pekerjaannya. 


\section{KESIMPULAN DAN SARAN}

Kesimpulan pada penelitian ini adalah kesalahan konsep banyak terjadi pada tahap menyusun strategi untuk memecahkan masalah. Kesalahan konsep dilakukan oleh siswa yang memiliki kepercayaan diri rendah, sedang maupun tinggi dengan kecemasan matematika rendah, sedang maupun tinggi. Kesalahan startegi dilakukan oleh siswa yang memiliki kepercayaan diri rendah, sedang maupun tinggi dengan kecemasan matematika rendah, sedang maupun tinggi pada tahap melaksanakan strategi yang telah direncanakan. Kesalahan operasi hitung dilakukan oleh siswa yang memiliki kepercayaan diri rendah, sedang maupun tinggi dengan kecemasan matematika rendah, sedang maupun tinggi pada tahap melakukan pemeriksaan kembali.

Saran untuk penelitian selanjutnya adalah dapat melakukan penelitian terkait pengembangan pembelajaran untuk mengurangi kesalahan konsep, kesalahan strategi dan kesalahan operasi hitung yang dilakukan oleh siswa. Selain itu, dapat melakukan wawancara yang lebih mendalam dalam menggali informasi dan memperkuat hasil penelitian.

\section{DAFTAR PUSTAKA}

Anugraheni, I. (2019). Pengaruh Pembelajaran Problem Solving Model Polya Terhadap Kemampuan Memecahkan Masalah Matematika Mahasiswa. Jurnal Pendidikan, 04(01), 1-6.

Aristiani, R. (2016). Meningkatkan Percaya Diri Siswa melalui Layanan Informasi Berbantuan Audiovisual. Jurnal Konseling Gusjigang, 2(2), 182-189.

$\begin{array}{cc}\text { Budiyono. (2017). } & \text { Pengantar } \\ \text { Metodologi } & \text { Penelitian }\end{array}$
Pendidikan.

Disai, W. I., Dariyo, A., \& Basaria, D. (2014). Hubungan Antara Kecemasan Matematika Dan SelfEfficacy Dengan Hasil Belajar Matematika Siswa SMA X Kota Palangkaraya. Jurnal Muara Ilmu Sosial, Humaniora Dan Seni, 1(2), 556-568.

Ekawati, A. (2015). Pengaruh kecemasan terhadap hasil belajar matematika siswa kelas vii smpn 13 banjarmasin 1. Math Didactic: Jurnal Pendidikan Matematika, 1(3), 164-169.

Fenti, Sudia, M., \& Kadir. (2020). Pengaruh Motivasi Belajar dan Tingkat Kepercayaan Diri terhadap Hasil Belajar Matematika. Amal Pendidikan, 1(1), 31-41.

Irfan, M. (2017). Analisis Kesalahan Siswa dalam Pemecahan Masalah Berdasarkan Kecemasan Belajar Matematika. Kreano, 8(2), 143149.

Komara, I. B. (2016). Hubungan antara Kepercayaan Diri dengan Prestasi Belajar dan Perencanaan Karir Siswa. Psikopedagogia, 5(1), 3342.

Lutfiyah, L., Rukmigarsari, E., \& Fathani, A. H. (2019). Pengaruh Kecemasan Matematika Dan Kepercayaan Diri Terhadap Kemampuan Pemecahan Masalah Matematis Siswa Pada Materi Aritmetika Sosial SMP Negeri 14 Malang. Pendidikan Dan Profesi Pendidik, 14(6), 49-53.

Mukeriyanto, Mastur, Z., \& Mulyono. (2019). Kemampuan Pemecahan Masalah Matematika Menggunakan Model Pembelajaran Kancing Gemerincing Berbasis Budaya Jawa. Prisma 2, 171-177. 
DOI: https://doi.org/10.24127/ajpm.v10i2.3644

Ningsi, G. P. (2018). Analisis Kesalahan Siswa dalam Memecahkan Masalah Matematika Menurut LangkahLangkah Pemecahan Masalah. KNPMP III. 44-51.

Purnama, S., \& Mertika. (2018). Analisis Kemampuan Pemecahan Analisis Kemampuan Pemecahan Masalah Siswa Ditinjau dari Self Confidence. Of Educational Review and Research, 1(2), 5963.

Saputra, P. R. (2014). Kecemasan Matematika dan Cara Menguranginya (Mathematic Anxiety and How To Reduce IT). Pythagoras, 3(2), 75-84.

Sukendra, I. K. (2018). Hubungan Antara Tingkat Kecemasan dan Kemampuan Berpikir Logis Terhadap Hasil Belajar Matematika. Emasains, VII(1), 91-98.

Sumartini, T. S. (2016). Peningkatan Kemampuan Pemecahan Masalah Matematis Siswa melalui Pembelajaran Berbasis Masalah. Jurnal Pendidikan Matematika, $5(2)$.

Ulya, H. (2016). Profil Kemmpuan Pemecahan Masalah Siswa Bermotivasi Belajar Tinggi Berdasarkan Ideal Problem Solving. Jurnal Konseling GUSJIGANG, 2(1), 90-96.

Yuwono, T., Supanggih, M., \& Ferdiani, R. D. (2018). Analisis Kemampuan Pemecahan Masalah Matematika dalam Menyelesaikan Soal Cerita Berdasarkan Prosedur Polya. Jurnal Tadris Matematika, 1(2), 137-144. 